\title{
Henkilöstön kehittämisen kohteet ja tulosalueet
}

\section{Kohteina taitotieto ja tahto}

Henkilöstön kehittäminen on yhteinen, kokoava nimitys niille tietoisesti suunnitelluille prosesseille, joilla henkilöstön pätevyyttä parannetaan. Pätevyys on pätevyyttä johonkin; sillä on aina kohteensa. Pätevyyden ehtona on, että yksilö omaa tarvittavan taitotiedon. Se ei yksinään kuitenkaan riitä. Jos tahto puuttuu, jää taitotieto käyttämättä. ven työhön liittyvät asenteet ja arvot saattavat yllättää. Tahdon merkitys korostuu myös vanhenevien ikäluokkien suunnasta. Työuran laki on saavutettu. Haasteita ja uuden oppimista ei ehkä ole näköpiirissä. Leipiintyminen uhkaa ja varhaiseläke houkuttelee. Tilanteen syynä ovat pikemmin kehittymistä ehkäisevät asenteet ja vakiintuneet toimintamallit kuin taitotiedon puute sinänsä.

Näin virittyvät henkilöstön kehittämisen välittömät, konkreetit kohteet eli se, mitä kehitetään. Yksinkertaisesti joko taitotietoa tai tahtoa.
Viime vuosikymmen painotti henkilöstön kehittämisessä tietoa. Kasvatustieteellisellä ammattifraseologialla ilmaistuna laaja-alaisia, kognitiivisia rakenteita, jotka säilyvät muistissa hyvin ja muodostavat laaja-alaisen orientaatioperustan käytännön työtoiminnassa esiintyvien ongelmien ratkaisemiseksi.

Tahdon eli työskentelyn motivaation turvaaminen laajasti käsitettynä, jäi ymmärrettävästi vähemmälle. Henkilöstön kehittämisessä joudutaan 1990-luvulla hyväksymään henkilöstön työskentelytahdon turvaaminen yhdeksi toiminnan kohteeksi.
Joustavuus, liikkuvuus, monitaitoisuus ja laaja-alainen ammattitaito ovat nykyisin suosittuja sanoja. Kun niihin vielä liitetään tulosjohtamisen käsite, on luotu iskevä ja myyvä mielikuva. Valitettavan harvoin näkee kysyttävän, mitä mielikuva merkitsee henkilöstön kehittämisen kannalta: onko iskevyys ja myyvyys silkkoa sisältä vai kyetäänkö haasteisiin vastaamaan?

\section{Kolme tulosaluetta}

Henkilöstön kehittämisen kustantaa tavallisesti työnantaja, jolla on sen vuoksi oikeus, jopa velvollisuus vaatia toiminnalta näkyviä vaikutuksia, tuloksia. Kehittämisvaikutusten kirjo on laaja. Sen muokkaaminen muutamaksi harvaksi ryppääksi, tulosalueeksi on vaikeaa ja kritiikille altista.

Kuitenkin vaikuttaa siltä, että tärkeimmät henkilöstön kehittämisen tulosalueet ovat (1) työtehtävien suorittamisen tehostuminen, (2) organisaation oppiminen ja (3) henkilöstön työmarkkinakelpoisuuden parantuminen.
Nuorella, työelämään siirtyvällä sukupolvella on tasokas ammatillinen peruskoulutus. Taitotieto ei ole ongelma; sitä vastoin nousevan sukupol-
Työtehtävien suorittamisen tehostuminen eli työsuoritus on perinteinen henkilöstön kehittämisen tulosalue. Se on myös helpoiten mitattava, 
selkein ja konkreettisin kehittämistoimien perusta. On selvää, että jos osaaminen organisaatiossa on puutteellista, ajaudutaan vaikeuksiin.

Osaaminen, taitotiedon puute on nykyisin yhä harvemmin organisaation vaikeuksien syynä. Yhä useammin joudutaan pohtimaan, miksi asiat eivät osaamisesta huolimatta suju toivotulla tavalla. Henkilöstön kehittämisen painopiste on siirtymässä.

Organisaation oppiminen ja yksilön työmarkkinakelpoisuus ovat tulosalueina vähemmän tunnettuja, kenties myös vähemmän hyväksyttyjä siitä huolimatta, että henkilöstön kehittämisen painopiste näyttää siirtyvän niiden suuntaan: voimakas kilpailu korostaa organisaation oppimiskyvyn tärkeyttä. Yksilön työmarkkinakelpoisuuden edistämistä taas painotettiin äskettäin ilmestyneessä henkilöstökomitean mietinnössä.

\section{Organisaation oppiminen}

Oppimisen perinteisessä, yksilöön liittyvässä merkityksessä on selvää, ettei organisaatio sinänsä voi oppia mitään. Silti organisaatiot säilyvät ja käyttäytyvät ennakoitavasti, vaikka yksilöt menevät ja tulevat. Kun uusi jäsen liittyy organisaatioon, hän kohtaa valmiin todellisuuden, johon hän sopeutuu. Näin organisaatiot siirtävät ajattelun ja toiminnan malleja sekä traditioita sukupolvelta toiselle.

Organisaatiolla on enemmän tai vähemmän selkeäksi kiteytynyt tehtävistö, joka on luonteeltaan pysyvähkö. Sitä vastoin organisaation ulkoinen ja sisäinen ympäristö eli toimintatodellisuus muuttuu jatkuvasti. Tehokas tehtävistön suorittaminen edellyttää toimintatodellisuuden jatkuvaa seurantaa ja reagoimista muutoksiin. Puutteellinen toimintatodellisuuden seuranta aiheuttaa sen, että organisaatio ruvetaan mieltämään tyypilliseksi byrokratiaksi ja pahimmillaan historian luutuneeksi jäänteeksi.

Organisaation oppimisella ymmärretään tavallisesti sen kykyä seurata toimintatodellisuuden muutoksia. Henkilöstö keskustelee ja viestii niistä muutoksista, epäkohdista, uhista ja mahdollisuuksista, joita toimintatodellisuudessa esiintyy. Vuorovaikutuksen myötä organisaation strategia selkiytyy, organisaatiokulttuuri hioutuu ja näin tehtävistö kyetään suorittamaan tehokkaasti myös muuttuvassa toimintatodellisuudessa.

Organisaation oppiminen on siihen kuuluvien yksilöiden vuorovaikutuksen tulos. Vuorovaikutuksen tavat, rakenteet ja mallit muuttuvat hitaasti, ja ovat usein tiedostamattomia. Organisaation oppimiskyvyn kehittämisen lähtökohtana on siten lisätä toimintatodellisuudesta saatavaa palautetta.

Palautteen laatuun ja määrään vaikutetaan ilmeisen suoraviivaisesti siten, että vähennetään yksilön tarvetta suojautuvaan käyttäytymiseen. Jos toiminta ohjautuu epäonnistumisen pelosta, roolin ja kasvojen säilyttämisen tarpeesta tahi sanktioiden uhasta, ovat rehellisen ja suoran toimintatodellisuuden analyysin mahdollisuudet vähäisiä. Käytännössä tämä tarkoittaa sitä, että organisaatio uskottelee elävänsä toisenlaisessa toimintatodellisuudessa kuin elää. Suojaudutaan, rakennetaan eristäviä valleja ja selitellään ongelmia organisaatioon negatiivisesti asennoituvien päättäjien tuottamiksi.

Organisaation oppiminen ei ole päämäärä sinänsä. Se on väline, jonka avulla pyritään varmistamaan tehokas tehtävistön suorittaminen. Ilmeisesti organisaation oppimiskyvyn merkitys kasvaa toimintatodellisuuden muutosten myötä: mitä muuttuvampi toimintatodellisuus, sitä tärkeämmäksi oppimiskyky käy.

Organisaation oppimiskykyä ei voi kehittää suoraan. Se kasvaa, se viihtyy siellä, missä kliseenomaisesti sanoen tehokkaiden työsuoritusten lisäksi oppimiskyvyn lannoitteena ovat ilo, nauru, kokeilunhalu ja innovatiivisuus. Tällöin yksilö saattaa konkreettisten työsuoritusten palkitsevuuden lisäksi sitoutua myös henkisesti organisaation toiminta-ajatukseen.

\section{Työmarkkinakelpoisuus}

Työmarkkinakelpoisuus ilmenee yksilön haluna ja kykynä liikkua työmarkkinoilla työtehtävästä toiseen; mahdollisesti jopa ylittää korkeahkona pidetty kynnys julkisen ja yksityisen sektorin välillä. Työmarkkinakelpoisuuteen kytkeytyvät läheisesti tärkeinä pidetyt joustavuuden ja liikkuvuuden käsitteet. 
Joustavuus on organisaation kykyä muuttua toimintatodellisuuden vaatimalla tavalla siten, ettei muutoksesta aiheudu merkittäviä lisäkustannuksia. Henkilöstöltä se edellyttää kykyä suorittaa laajahkoja työkokonaisuuksia ja luopumista tarkoista, tehtäväsidonnaisista työrooleista. Monipuolista, laaja-alaista taitotietoa tarvitaan. Lisäksi tarvitaan tahtoa käyttää taitotietoa tavalla, joka poikkeaa vanhasta, tarkasti työtehtäviä jaottelevasta ajattelutavasta.

Joustavuutta voidaan ilmeisesti pitää päämääränä, jonka keinoja ovat esimerkiksi yleisen työmarkkinakelpoisuuden lisääminen vaikkapa ammatillisen lisäkoulutuksen avulla sekä toisaalta henkilöstön liikkuvuus. Luonnollisesti ne limittyvät ja lomittuvat toisiinsa. Yhdessä ne johtavat laaja-alaiseen ammattitaitoon, joka mahdollistaa organisaation ja myös koko kansantalouden joustavuuden.

Yksilön työmarkkinakelpoisuus on henkilöstön kehittämisen tulosalueena tuore. Se murtaa perinteistä, organisaatiokeskeisen henkilöstön kehittämisen ajattelutapaa ja edellyttää sen vuoksi uudenlaista asennoitumista.

Aiemmin henkilöstön kehittämisen mielekkyyttä arvioitiin lähinnä sen perusteella, miten edistetään tietyn organisaation, viraston tahi laitoksen toimintaa. Lähtökohtana oli yksittäisen instanssin etu.

Työmarkkinakelpoisuuden parantamisen lähtökohtana on sitä vastoin koko kansantalouden etu. Yhden organisaation näkökulmasta, erityisesti lyhyellä aikajänteellä tarkasteltuna, ei yksilön yleisen työmarkkinakelpoisuuden parantuminen välttämättä ole myönteinen ilmiö: henkilöstön liikkuvuus lisääntyy ja henkilöresurssien hallinta vaikeutuu.

Sitä vastoin kansantalouden näkökulmasta työmarkkinakelpoisuuden lisääntyminen liikkuvuuden avulla parantaa kansantalouden joustavuutta ja varmistaa sen, että sopivan ja tosiasiallisen pätevyyden omaava työvoima on oikeaan aikaan oikeassa paikassa.

\section{Henkilöstön kehittämisen haasteita}

Henkilöstön kehittämisen haasteet vaihtelevat organisaatioittain suuresti. Sen vuoksi tässä on mielekästä keskittyä ainoastaan niihin, jotka oletettavasti tulevat esiintymään lähes kaikissa organisaatioissa; toisin sanoen ovat kehityksen säikeitä.

Ehkäpä merkittävin kehityksen säie on, että traditionaalisesta yksilö - organisaatio vastakkainasettelusta lienee pikku hiljaa syytä luopua. Liikkuvuus on kansantaloudellinen etu. Yksilölle se tarjoaa mahdollisuuden kehittyä ja löytää juuri hänen ominaisuuksilleen sovelias työ. Ilmeisesti tyytyväisyys, oma-aloitteisuus ja vastuullisuus sen myötä lisääntyvät. Näin yksilöiden ja organisaatioiden edut käyvät yksiin ja kietoutuvat toisiinsa.

Henkilöstön kehittämiselle tämä, sinänsä myönteinen kehitys on haaste. Aihealueen kirjallisuus ja tutkimus on pääsääntöisesti suuntautunut tarkastelemaan ilmiötä joko-tai -asetelmista siten, että ristiriitaisiksi hahmotetuista eduista on päädytty painottamaan työnantajan etuja. Henkilöstön kehittämisen mielekkyyden arviointi on perustunut organisaation hyötyyn.

Yllättäen väitetään, että yksilön hyöty on kansantalouden hyöty ja kansantalouden hyöty heijastuu ajan myötä organisaatioiden hyötynä. Ajattelutapa on laajentunut ja kääntynyt päälaelleen. On selvää, että murros vaatii aikansa.

Toinen, eri organisaatiot lävistävä kehityksen säie on organisaatioiden oppimisen edellytysten turvaaminen. Vain seuraamalla sisäisen ja ulkoisen toimintatodellisuutensa muutoksia, kykenee organisaatio vastaamaan joustavuuden, liikkuvuuden ja kilpailun haasteisiin. Henkilöstön monensuuntaisen vuorovaikutuksen edistäminen, kokeilun ja innovatiivisuuden kirvoittaminen tulevat yhä keskeisemmiksi henkilöstön kehittämisen tavoitteiksi.

Samalla työntekijän ja työnantajan usein tiedostamattoman psykologisen sopimuksen oikeaan osuvuuden merkitys kasvaa. Jos edellytetään aloitteellisuutta, vastuuta ja innovatiivisuutta, on siihen luotava tosiasialliset edellytykset. Lähimenneisyyden kokemuksista tiedetään, että yhteiskunnallisen tai organisatorisen kontrollin ja säätelyn mahdollisuudet ovat heikot ja todelliset tulokset masentavia.

Aloitteellisuus, vastuullisuus ja innovatiivisuus ovat pitkälti yksilön kantamia ominaisuuksia, hänen kvalifikaatioitaan. Nïden käyttö on sisäsyn- 
tyisesti palkitsevaa, iloa ja onnistumisen kokemuksia tuottavia. Niiden käyttöön ei voida pakottaa. Niitä käytetään jos yksilö (henkilöstö) kokee työnantajan arvostavan hänen työtään, tarjoavan kohtuulliset ulkoiset puitteet sekä luottamuksen.

Kehityssuunnan myötä taitotiedon merkitys saattaa näennäisesti jonkin verran henkilöstön kehittämisessä vähetä. Oleelliseksi tullee, miten or- ganisaatiorakenteet avataan, miten luodaan työssä oppimiselle edellytykset ja miten kyetään raivaamaan muutokselle alaa.

Tämä suuntaa henkilöstön kehittämistä aiempaa pehmeämpään lähestymiseen. Ilmeisesti työtä itsessään pyritään opinnollistamaan samalla, kun henkilöstön kehittäminen muuttuu kokonaisvaltaisemmaksi. Lähtökohtana on yksilö, hänen taitotietonsa ja tahtonsa.

\section{Taulukko 1. Henkilöstön kehittämisen kohteiden ja tulosalueiden jäsenyys ja havainnollistus}

\begin{tabular}{|c|c|c|c|}
\hline \multirow[b]{2}{*}{$\begin{array}{l}\text { Henkilöstön } \\
\text { kehittämisen } \\
\text { kohde }\end{array}$} & \multicolumn{3}{|c|}{ Henkilöstön kehittämisen tulosalue } \\
\hline & Työsuoritus & $\begin{array}{l}\text { Organisaation } \\
\text { oppiminen }\end{array}$ & $\begin{array}{l}\text { Yksilön } \\
\text { työmarkkina- } \\
\text { kelpoisuus }\end{array}$ \\
\hline Taitotieto & Työn tehokkuus & $\begin{array}{l}\text { Ulkoinen ja sisäinen } \\
\text { palautejärjestelmä }\end{array}$ & $\begin{array}{l}\text { Työvoiman jousta- } \\
\text { vuus ja liikkuvuus }\end{array}$ \\
\hline Tahto & $\begin{array}{l}\text { Työnteon motiivien } \\
\text { luonne ja intensi- } \\
\text { teetti }\end{array}$ & $\begin{array}{l}\text { Sitoutuneisuus } \\
\text { organisaation } \\
\text { toiminta-ajatukseen }\end{array}$ & $\begin{array}{l}\text { Halu laajaan osaami- } \\
\text { seen ja sen laajaan } \\
\text { hyödyntämiseen }\end{array}$ \\
\hline
\end{tabular}

\section{Silkkoako sisältä?}

Sen näyttää lähitulevaisuus. Todennäköisyyksiä voidaan ennakoida. Henkilöstön kehittämisen teorian ja periaatteiden tasolla uuden, moniulotteisemman ajattelutavan idut ovat olemassa. Käytäntö luo itujen maaperän.

Henkilökohtaisesti epäilen mullan muhevuutta. Tutkimuksissa on osoitettu, että organisaatioiden luonne vaihtelee maittain ja organisaatiokulttuuri on vaikea muutettava. Kun lisäksi huomioidaan taloudellisen optimismin väheneminen ja siihen sitoutuvan henkisen muutoksen vaikeutuminen, joudutaan henkilöstön kehittämisen tuloksia kenties aiempaakin voimallisemmin tarkastelemaan työsuoritusten tasolla.

Pitkäjännitteisen, organisaation oppimista, yksilön työmarkkinakelpoisuutta ja kansantalouden etua painottavan henkilöstön kehittämisen läpimurron todelliset mahdollisuudet eivät siten ole niin auvoisia kuin äkkipäätään olettaisi.

Henkilöstön kehittämisen kohteita ja tulosalueita havainnollistuksineen taulukossa 1. 